\title{
Society for Pediatric Research Presidential Address 2008: Can Pediatric Research Benefit from Global Warming?
}

\author{
PHYLLIS A. DENNERY
}

Department of Pediatrics, University of Pennsylvania, Philadelphia, Pennsylvania 19104

$\mathbf{I}_{\mathrm{i}}^{\mathrm{t}}$ we use the words global warming to describe the environmental phenomenon that is threatening our way of life through our own doing, we contemplate the shifting of our previously stable environment, to an inhospitable one (1). This justifiably brings fear and dread to our minds. In the context of this talk, this is not what I am referring to, though I will illustrate parallels between environmental global warming and trends in pediatric research.

In environmental global warming, the principal culprits are North America and Europe, followed closely by Asia. These nations impact the resources and climate of the rest of the world. A parallel can be drawn to pediatric research where industrialized nations have claimed their dominance in publications and in scientific advance, but are we, the scientists of these industrialized nations, too satisfied with ourselves to observe the impact we have on others and their impact on us? Scientific knowledge, like the calving glacier, has ripple effects globally. In the case of the glacier, it melts into the sea causing sea levels to rise. This results in dire and immutable consequences throughout the world and a changing landscape (1). In the case of the dissemination of knowledge obtained through pediatric research, this also has important global implications that change the scientific and clinical landscape. As an example of the global impact of pediatric research, an international collaboration on childhood leukemia demonstrates this well.

There is tremendous inequity in the outcomes of childhood leukemia throughout the world. The cure rate for acute lymphocytic leukemia (ALL) is $80 \%$ in the developed world whereas in developing countries this rate can be $10 \%$ or lower (2). Since 1992, under the guidance of various groups including the National Cancer Institute, several Pediatric Oncology workshops were held throughout the world to unify risk criteria and to collect information on patients with ALL, so as to better guide therapy and to foster research. The creation of pediatric cancer units to optimize the limited resources that often plague the developing nations, the establishment guidelines for care, the dissemination of information, and most importantly, twining, or the pairing of units in developing nations with those in developed nations, resulted in improved survival rates and promoted more research to further improve outcomes (2).

Received August 4, 2008; accepted August 7, 2008

Correspondence: Phyllis A. Dennery, M.D., Division of Neonatology, Children's Hospital of Philadelphia, Philadelphia, PA 19104; e-mail: dennery@email.chop.edu

Presented at the 2008 Annual Meeting of the Pediatric Academic Societies, Honolulu, Hawaii.
Another example of global benefits from pediatric research is the recent discovery of functional polymorphisms in inositol 1,4,5-trisphosphate 3-kinase C, a gene important to the susceptibility and to the formation of coronary aneurysms in $\mathrm{Ka}$ wasaki disease (3). Genetic factors were suspected, as the disease is 10 to 20 times more prevalent in Japan. In addition, siblings of affected children are at 10 times higher risk than the general population. Through an international collaboration, linkage disequilibrium mapping was conducted in sibling pairs from Japan and transmission disequilibrium test analysis was conducted in the United States, using multiethnic family triads. A candidate gene was identified and functional studies further delineated the role of this gene in T-cell activation and cell signaling (3). In both of the above examples, the knowledge gained had global impact.

In the harsh reality of environmental global warming, the previously content creature, luxuriating in its habitat, has to adapt rapidly to an inhospitable world. It is hard to conceive that any good could result from this. In pediatric research, adapting to hostile environments by creating global opportunities has proven to be quite successful. In recent years, the government of South Africa decided that the best approach to managing HIV/AIDS is to ignore it. The stigma of the disease was more important than its victims who are now faced with devastatingly difficult conditions. Thankfully, through a multinational collaboration, blood samples from patients with AIDS in South Africa were analyzed in the United States, Britain, and Australia as to HLA markers through restriction assays, HLA typing and viral sequencing. This led to the important discovery that HLA-B is the key in mediating the evolution of HIV. This has considerable implications for vaccine development. This is a success story achieved through international collaboration, global warming (4). Another example of adapting to harsh environments is the situation requiring adaptation to war. In 2006, Iraqi investigators teamed with Italian investigators to implement a protocol for promyelocytic leukemia in children (5). The solution to the high mortality rates seen in Iraqi children was as simple as providing all-trans-retinoic acid (ATRA) to improve survival rates. Wartime had resulted in depletion of important therapeutic agents including ATRA. Through this international collaboration, Roche, Italy provided ATRA to the Iraqis. This resulted in a significant change in long-term survival (10\% versus $78 \%$ )

Abbreviations: ALL, acute lymphatic leukemia; ATRA, all-trans-retinoic acid 
(5). Once again, a positive outcome from an inhospitable environment achieved through global warming.

To further the point about harsh environments, I will discuss the concerns with stem cell research in the United States, where policies have made it difficult for individuals interested in embryonic stem cell research. We currently have a president who equates this type of research with immorality. He in fact said, embryonic stem cell research "is at the leading edge of a series of moral hazards" (6). Luckily, through international collaborations, several investigators from many nations have generated cell lines from over 70 blastocysts that are available through a cell bank at the National Institutes of Health. This is allowing for continued insights into the characterization of stem cells and into optimization of engraftment strategist. In fact, a recent initiative has focused on understanding stem cell surface proteins through proteinomics (7). This is yet another example of overcoming inhospitable environments through global warming.

As a final example, in the United States, we are faced with the economic climate change at the National Institutes of Health and other funding agencies. As with Mount Kilimanjaro, the abundant ice cap is now nearly barren. The increasing demands, increasing cost of research and the decreasing resources make for a lethal combination for investigators. Global warming or international collaborations could allow for a pooling of resources from many nations to sustain funding for research. This should be a priority.

Multinational collaborations have another distinct advantage. This illustrates the power of numbers. Much too often, we are caught in a storm of meaningless information. The inconvenient truth is that this storm is of our own doing. We cannot see clearly through the pollution of small underpowered, poorly executed studies. Thankfully, large international collaborations allow us to see clearly and these are facilitated through global warming. One such example is the Cochrane collaboration. This group is based at multiple centers throughout the world. The group sets a clear objective and attempts to be broadly inclusive in answering questions based on the existing evidence in the literature. By pooling data of small studies, sound conclusions can be reached, which then guide practice (8).

The British Pediatric Orphan Lung Disease registry for rare pediatric lung diseases is another example where a multinational collaboration on a web-based registry resulted in enhanced reporting of these diseases (9). With more cases available for review and characterization, more can be learned about these diseases and better insights can be gained for clinical practice and future research.

As another example, a recent multinational collaboration demonstrating the efficacy of caffeine, not only for the treatment of apnea of prematurity, but also in the prevention of bronchopulmonary dysplasia and poor neurodevelopmental outcome superbly illustrates that there is strength in numbers (10).

Often, obtaining such large numbers of patients for trials can only be achieved by extending beyond our immediate circle. Again, through "global warming," that is international collaborations, wide-ranging beneficial outcomes are achieved in the care of children. From the haze of misinformation, we now achieve clarity through large international collaborative efforts and international registries. Smooth sailing ahead.

The Society for Pediatric Research (SPR) is poised to engage in "global warming." It has an international membership willing to be engaged in collaborative research. Until recently, the principal venue for interchange of ideas was through the Pediatric Academic Societies annual meeting. The new D.O.O.R. program, or Database Optimizing Opportunities in Research, will allow for access to a wealth of information on research interests of all members, further allowing for collaborations (11). Other mechanisms for interchange are the SPR-RC conference, which will be held again in 2009. In this forum, young investigators interact with experts in their field in a smaller more collegial environment. The bench to implementation grants will also allow for exchange of expertise between investigators within the SPR (12).

To specifically address "global warming" in pediatric research, the society will now offer international collaborative awards termed ICARUS. The mythical figure sought to soar beyond his perceived limitations, as we will try to overcome barriers to collaborating across continents. The success of Icarus was limited because he reached too far. Keeping this in mind, the scope of the initiatives will be realistically small. These awards will allow for exchange of expertise or research materials or personnel between two or more institutions in different continents to foster exchange and to complement each other's research, as illustrated in some of the examples previously discussed. Hopefully, this will enable individuals from nations with more limited resources to collaborate with colleagues from nations with more resources to better answer a research question. Eligible projects could be a pilot international collaborative study. Another type of project could involve an exchange of samples so as to allow experts with the appropriate technology to provide the analysis whereas in exchange, the technical experts benefit from a large patient population. Additionally, an exchange of personnel allowing junior investigators to be exposed to experts in the field could qualify. These are small steps in the right direction. Rather than isolating ourselves or competing against each other, we will join forces and achieve synergy and symbiosis through international collaborations for the better health of children. Pediatric research can benefit from "global warming" in many ways. I look forward to seeing this unfold.

It has been an honor to serve you, first as your SecretaryTreasurer, and now as your President. I also want to extend my sincere gratitude to my mentors and role models. Drs. Avroy Fanaroff and Richard Martin inspired me pursue a research career in Academic Neonatology. David Stevenson helped me navigate the turbulent waters of Academics. I am grateful to Maria Delivoria Papadopoulos, whom I met as a student 25 y ago and who has been a staunch supporter ever since. Debbie Anagnostelis and Kathy Cannon, thank you for putting up with me for the last 8 years. Your help has been invaluable. Peggy McDonald is an angel who keeps me sane in Philadelphia. And, John Sestito, my administrative director, keeps my work family financially safe and sound and is always there to get me out of trouble. 
All speakers thank their family, but I truly mean it. I was blessed with a mother who managed to be double boarded in Psychiatry and Pathology while raising six children in an era where women were not welcome in Medicine. I thank my father, a neurosurgeon who takes the time to paint, sculpt, and appreciate music from every continent. I am grateful to Ariana, my wonderful, artistic, and creative daughter who reminds me everyday that there is a lot more to life than work. I am also grateful to Miles, my thoughtful, gentle, and socially aware son, who insists in fairness and keeps me honest. Gregory Mundy, my husband of 21 years, who has always supported me in my career, no matter how stressful, is my anchor.

Thank you everyone for your attention.

\section{REFERENCES}

1. Gore A 2006 An Inconvenient Truth. The Planetary Emergency of Global Warming and What We Can Do About It. New York, NY: Rodale Books

2. Pui CH, Ribeiro RC 2003 International collaboration on childhood leukemia. Int J Hematol 78:383-389

3. Onouchi Y, Gunji T, Burns JC, Shimizu C, Newburger JW, Yashiro M, Nakamura Y, Yanagawa H, Wakui K, Fukushima Y, Kishi F, Hamamoto K, Terai M, Sato Y, Ouchi K, Saji T, Nariai A, Kaburagi Y, Yoshikawa T, Suzuki K, Tanaka T, Nagai T, Cho H, Fujino A, Sekine A, Nakamichi R, Tsunoda T, Kawasaki T, Nakamura Y, Hata A 2008 ITPKC functional polymorphism associated with Kawasaki disease susceptibility and formation of coronary artery aneurysms. Nat Genet 40:35-42

4. Kiepiela P, Leslie AJ, Honeyborne I, Ramduth D, Thobakgale C, Chetty S, Rathnavalu P, Moore C, Pfafferott KJ, Hilton L, Zimbwa P, Moore S, Allen T, Brander
C, Addo MM, Altfeld M, James I, Mallal S, Bunce M, Barber LD, Szinger J, Day C, Klenerman P, Mullins J, Korber B, Coovadia HM, Walker BD, Goulder PJ 2004 Dominant influence of HLA-B in mediating the potential co-evolution of HIV and HLA. Nature 432:769-775

5. Testi AM, Al-Hadad SA, Al-Jadiry MF, Moleti ML, Mandelli F, Foa R 2006 Impact of international collaboration on the prognosis of childhood acute promyelocytic leukemia in Iraq. Haematologica 91:509-512

6. Bush GW 2001 President discusses stem cell research. Available at: http:// www.whitehouse.gov/news/releases/2001/08/20010809-2.html. Accessed August 8,2008

7. Adewumi O, Aflatoonian B, Ahrlund-Richter L, Amit M, Andrews PW, Beighton G, Bello PA, Benvenisty N, Berry LS, Bevan S, Blum B, Brooking J, Chen KG, Choo AB, Churchill GA, Corbel M, Damjanov I, Draper JS, Dvorak P, Emanuelsson K, Fleck RA, Ford A, Gertow K, Gertsenstein M, Gokhale PJ, Hamilton RS, Hampl A, Healy LE, Hovatta O, Hyllner J, Imreh MP, Itskovitz-Eldor J, Jackson J, Johnson JL, Jones M, Kee K, King BL, Knowles BB, Lako M, Lebrin F, Mallon BS, Manning D, Mayshar Y, McKay RD, Michalska AE, Mikkola M, Mileikovsky M, Minger SL, Moore HD, Mummery CL, Nagy A, Nakatsuji N, O'Brien CM, Oh SK, Olsson C, Otonkoski T, Park KY, Passier R, Patel H, Patel M, Pedersen R, Pera MF, Piekarczyk MS, Pera RA, Reubinoff BE, Robins AJ, Rossant J, Rugg-Gunn P, Schulz TC, Semb H, Sherrer ES, Siemen H, Stacey GN, Stojkovic M, Suemori H, Szatkiewicz J, Turetsky T, Tuuri T, van den Brink S, Vintersten K, Vuoristo S, Ward D, Weaver TA, Young LA, Zhang W 2007 Characterization of human embryonic stem cell lines by the International Stem Cell Initiative. Nat Biotechnol 25:803-816

8. Haugh MC, Boissel JP, Pignon JP, Chalmers I 1996 [The Cochrane Collaboration: the need for international collaboration]. Therapie 51:253-256

9. Laverty A, Jaffe A, Cunningham S 2008 Establishment of a web-based registry for rare (orphan) pediatric lung diseases in the United Kingdom: the BPOLD registry. Pediatr Pulmonol 43:451-456

10. Schmidt B, Roberts RS, Davis P, Doyle LW, Barrington KJ, Ohlsson A, Solimano A, Tin W 2006 Caffeine therapy for apnea of prematurity. N Engl J Med 354:21122121

11. Shaul PW 2007 The cold, hard truth about pediatric research. Pediatr Res 61:506509

12. Freed GL 2007 Society for Pediatric Research-2007 presidential address: expanding the research continuum-from bench to implementation. Pediatr Res 62:370-373 